\title{
Yöneticilerin Olumlu ve Olumsuz Mizah Kullanımı ile Çalışan Tutumları Arasındaki İlişki
}

\section{The Relationship Between Positive and Negative Use of Humor of Managers and Employee Attitudes}

\section{Dr. Öğr. Üyesi Ozan Büyükyılmaz ${ }^{1}$}

Başvuru Tarihi: 13.09.2018

Kabul Tarihi: 09.11.2018

Öz

Bu çalışmanın amacı, yöneticilerin olumlu ve olumsuz mizah kullanımı ile çalışanların çeşitli iş tutumları arasındaki ilişkiyi belirleyebilmektir. Bu çerçevede olumlu ve olumsuz mizah kullanımı ile iş tatmini, duygusal bağlılık ve lider-üye etkileşimi arasındaki ilişkiler araştırılmaktadır. Analizlerde kullanılan veri, Karabük Üniversitesi Sosyal Bilimler Enstitüsü’nde öğrenim gören ve bir özel veya kamu kurumunda çalışmakta olan 325 lisansüstü öğrencisinden anket yoluyla elde edilmiştir. Araştırma hipotezleri hiyerarşik regresyon analizi ile test edilmiştir. Araştırmanın sonucunda, yöneticilerin hem olumlu hem de olumsuz mizah kullanımının çalışan tutumlarını etkilediği, fakat olumsuz mizah kullanımının daha güçlü bir etkiye sahip olduğu belirlenmiştir.

Anahtar Kelimeler: Yönetici Mizah Tarzları, Olumlu ve Olumsuz Mizah, İş Tatmini, Duygusal Bağlllık, Lider-Üye Etkileşimi

\begin{abstract}
The purpose of this study is to determine the relationship between the positive and negative use of humor of managers and the various job attitudes of employees. Within this scope, the relationship between positive and negative humor and job satisfaction, affective commitment and leadermember exchange are investigated. The data used in the study were gathered by questionnaire from 325 graduate students studying at the Karabuk University Institute of Social Sciences and at the same time working in a state and private organization. Research hypotheses were tested by hierarchical regression analysis. As a result of the study, it was determined that both positive and negative use of humor of managers affect employee attitudes, but negative use of humor has a stronger influence.
\end{abstract}

Keywords: Managerial Humor Styles, Positive and Negative Humor, Job Satisfaction, Affective Commitment, Leader-Member Exchange

\footnotetext{
${ }^{1}$ Karabük Üniversitesi İșletme Fakültesi, ozanbuyukyilmaz@karabuk.edu.tr, ORCID: 0000-0001-5499-1485
} 


\section{Giriş}

Mizah herkes tarafından bilinmekte ve kullanılmakta, insanlar arasında hoşgörü yaratmakta ve dolayısıyla insan deneyiminin son derece anlamlı bir yönünü oluşturmaktadır. Mizahi durumların kaçınılmaz olması ve mizahın geniş kapsamlı sonuçlarının bulunması, iş hayatında ve örgütlerde mizahın araştırılmasını gerekli kılan iki önemli neden olarak gösterilebilir.

Mizahın farklı örgütsel süreçleri kolaylaştırabileceği belirtilmektedir. Mizah, işyerinde ilişkileri kurmaya ve desteklemeye yardımcı olmakta (Cooper, 2008), grup süreçlerini kolaylaştırmakta (Romero ve Pescosolido, 2008), çalışanların stresle başa çıkmasını sağlamakta (Doosje vd., 2010) ve problem çözmede yaratıcılığı artırmaktadır (Holmes, 2007). Mizahı iyi kullanan liderlerin daha çok sevildiği düşünülmektedir (Holmes ve Marra, 2002; Hughes ve Avey, 2009). Çeşitli olumlu etkilerine rağmen mizahın aynı zamanda olumsuz yönleri de bulunmaktadır. Örneğin, çalışanların işlerinden uzaklaşması, güvenilirliğin zedelenmesi veya farklı yapıdaki bireylerin bulunduğu çalışma ortamlarında kırılmalar gibi olumsuzluklar meydana getirebilmektedir (Scheel ve Gockel, 2017). İş hayatında olumsuz mizah kullanımı, hedeflenen kişiye karşı önyargı oluşmasını sağlayarak düşmanlığı arttırabilir (Janes ve Olson, 2015), çalışanların yabancılaşmasına ve iyi çalışanların örgütten ayrılmasına neden olabilir (Plester, 2009), işyerinde ayrımcılı̆̆ın yükselmesine yol açabilir (Quinn, 2000) ve yöneticinin itibarı üzerinde olumsuzluk yaratarak yönetici kararlarını anlamsızlaştırabilir (Lyttle, 2007).

Mizah aslında insan doğasının ve insan ilişkilerinin özünde var olan bir unsurdur. Mizah ve kahkaha, tüm kültürlerde ve dünyadaki hemen hemen tüm bireylerde meydana gelen insan deneyiminin evrensel bir yönüdür (Martin, 2007, s. 2). Dolayısılla mizahın birçok alanda akademik olarak incelenen önemli bir kavram olduğu söylenebilir. Bu çerçevede gülme ve mizah arasındaki ilişki (Gervais ve Wilson, 2005), mizahın zihinsel ve fiziksel sağlık üzerindeki etkileri (Galloway ve Cropley, 1999; Martin, 2001), mizah ve kişilik ilişkisi (Mendiburo-Seguel vd., 2015) ve romantik ilişkilerde mizah kullanımı (Wilbur ve Campbell, 2011; Hall, 2017) gibi alanlarda çok sayıda araştırma bulunmaktadır. Her ne kadar son yıllarda liderlerin ve çalışanların mizah kullanımı konusuna daha fazla ilgi gösterilse de, iş hayatında ve örgütlerde mizah üzerine gerçekleştirilen sınırlı sayıda araştırma bulunmaktadır.

İş hayatında mizah kullanımı ile ilgili gerçekleştirilen literatür araştırmalarının, yönetimsel iletişim (Wood vd., 2011) ve işyerinde mizah yönetimi (Lyttle, 2007) gibi örgüt yönetimi perspektifini içerdiği görülmektedir. Ayrıca, işyeri ilişkilerinde mizah kullanımı (Cooper, 2008), mizah tarzları ve liderlik gibi çalışma bağlamları üzerindeki etkileri (Romero ve Cruthirds, 2006), örgüt iklimi kapsamında mizah ve duygular (Robert ve Wilbanks, 2012) gibi alanlarda literatür araştırmaları da gerçekleştirilmiştir. Her ne kadar bu incelemeler faydalı olsa da, bu incelemelerde mizahın işlevleri üzerine söylenenlerin büyük çoğunluğu ampirik olarak test edilmemiştir. Dolayısıyla bu çalışmalar gelecekteki araştırma girişimleri için başlangıç noktası durumundadır. 
Örgütlerde mizah, mizah kullanımı ve mizah tarzları üzerine bugüne kadar gerçekleştirilen araştırmalardan hareketle bu çalışma, yöneticilerin mizah tarzları ile çalışan tutumları arasındaki ilişkilere odaklanmaktadır. Çalışmanın amacı, yöneticilerin olumlu ve olumsuz mizah kullanımı ile çalışanların iş tatmini, duygusal bağllık ve lider-üye etkileşimi algıları arasındaki ilişkileri belirleyebilmektir.

\section{Kavramsal Çerçeve}

\section{Mizah Kavramı}

Bir araştırma konusu olarak mizah aslında yeni değildir. Tarih boyunca birçok teolog, filozof ve araştırmacı mizah kavramını tartışmıştır. Bu çerçevede mizahın farklı şekillerde tanımlandığı görülmektedir. Hipokrat’a göre mizah, insan vücudunun düzenlenmesine yardımcı olan dört akışkan vücut sıvısını (kan, balgam, sarı safra ve siyah safra) tanımlamaktır. Bu çerçevede mizah, insanın sağlıklı yaşamının bir parçasıdır (Martin, 2007, s. 20-21). Freud ise mizah kavramına psikolojik açıdan bakmakta ve kavramı, insanların zevk almak amacıyla kullandıkları bir savunma mekanizması olarak tanımlamaktadır (Scheel ve Gockel, 2017, s. 10).

Daha güncel araştırmalarda ise mizah kavramının daha geniş kapsamlı ve çok yönlü olarak ele alındığı görülmektedir. Bu bakış açısından mizah kavramına ilişkin tanımlarda mizahın, sürpriz, uygunsuzluk, idrak etme ve eğlence gibi farklı özellikler taşıdığı görülmektedir. Martin'e göre (2007, s. 11) mizah, alışılmış bir kalıp, bir yetenek, bir mizaç, bir estetik tepki, bir tutum, bir dünya görüşü, başa çıkma stratejisi veya bir savunma mekanizması olarak görülebilmektedir.

Long ve Graesser (1988, s. 37) mizahı "komik veya eğlenceli görülen, bilerek veya yanlışlıkla yapılan veya söylenen bir şey” olarak tanımlamaktadır. Martineau (1972, s. 114) ise mizah kavramını sosyolojik bir bakış açısılla incelemekte ve "mizahi olarak algılanan herhangi bir iletişimsel durum" olarak ifade etmektedir. Booth-Butterfield ve Booth- Butterfield'e göre ise (1991, s. 206), "hedeflenen alıcı için sürpriz, memnuniyet ve zevk anlamına gelen ve kahkaha, gülme ve diğer spontane davranış biçimlerini ortaya çıkaran kasıtlı sözlü ve sözsüz mesajlar" anlamına gelmektedir. Gervais ve Wilson (2005, s. 399) mizahın, bir anda ve ciddi olmayan sosyal ilişkilerde algılanan ani beklenmedik olay değişiklikleri sonucunda ortaya çıktığını belirtmektedir. Bu kapsamda mizahı "ciddi olmayan sosyal uyuşmazlık" şeklinde tanımlamaktadır. Hurren'e göre (2006, s. 11) mizah "alıcıda olumlu bir eğlence duygusu uyandıran sözlü ya da sözsüz herhangi bir mesaj” anlamına gelmektedir. Scheel ve Gockel ise (2017, s. 12) mizahı, uyuşmazlık içeren ve hem mizahın "yapımcısı" hem de "alıcısı" üzerinde çeşitli duyguları uyandıran iletişim süreci olarak görmektedir.

Mesmer-Magnus vd. (2012, s. 156) mizah kavramına ilişkin farklı tanımların bulunmasında dört faktörün etkisinden bahsetmektedir. Bunlar; (1) "mizah" ve "mizah duygusu" kavramlarının birbirinin yerine kullanılıyor olması, (2) mizahın çok boyutlu bir yapıya sahip olması, (3) çok farklı mizah türlerinin bulunması ve (4) bazıları olumlu ve bazıları olumsuz olmak üzere farklı mizah tarzlarının bulunmasıdır. 
Mizah, insanların yaşam içerisindeki davranış biçimlerini veya rutinlerini anlamamızı sağlarken, bu davranış biçimleri içerisindeki problemleri tanıma ve baş etme konusunda da yardımcı olmaktadır. Çünkü mizahın, diğer insanların davranış kalıplarını anlayış biçimiyle, bizim anlayışımızın nasıl benzer ya da farklı olduğunu açıkça ortaya koyma özelliği bulunmaktadır. Dolayısıyla mizahın, diğer insanların takip etmeyi düşündüğü iletişim biçimiyle ilgili belirsizliği azaltma konusunda katkısı büyüktür (Meyer, 2015, s. 3).

\section{Örgütlerde Mizah Kavramı}

Mizahın insanlar arası etkileşimde her zaman için varolması, farklı ve kapsamlı sonuçlara neden olması, ilginç bir olgu olarak iş hayatında ve örgütlerde incelenebilecek bir kavram olmasının temel nedenidir. Buna rağmen mizahın iş hayatında ve örgütlerde sıklıkla araştırılan bir konu olmadığı da bir gerçektir. Bunun temel nedeni olarak mizahın iş hayatı açısından ciddiye alınmayacak bir olgu olarak görülmesi ve kapsamında eğlence bulunan bir kavramın iş hayatına uygun olmadığının düşünülmesi gösterilebilir (Scheel ve Gockel, 2017, s. 2).

Yine de mizah potansiyel olarak iş hayatının tüm yönleriyle ilişkilidir. Mizah sadece eğlence için değildir. Çalışanlar arasındaki bütünleşmeyi artırmakta, yaratıcılığı geliştirmekte ve örgütsel gelişimi teşvik etmektedir (Holmes, 2007; Romero ve Pescosolido, 2008). Mizah çalışanlar arasındaki samimiyeti, dayanışmayı ve nezaketi arttırmaktadır (Holmes ve Marra, 2002, s. 65). Ayrıca örgütsel ikilimin iyileşmesine katkı sağlamaktadır ve etkin liderlikle yakından ilişkilidir. Mizahı iyi şekilde kullanabilen liderin "iyi” bir lider olduğuna inanılmaktadır (Liu ve Wang, 2016, s. 1307). Dolayısıyla mizah, çalışanlar arası ilişkilerden yönetim disiplinine kadar çeşitli amaçlarla kullanılabilen özünde değişkenlik bulunan bir olgudur (Butler, 2016, s. 421).

İş hayatında mizahı inceleyen araştırmaların sıklıkla örgütsel mizah kavramına odaklandığı görülmektedir. $\mathrm{Bu}$ kapsamda farklı araştırmacıların örgütsel mizah üzerine tanımlar gerçekleştirdiği görülmektedir. Cooper’a göre örgütsel mizah, çalışanların birbirlerini anlaması amacıyla kullanılan karmaşık ve ilginç bir olguyu ifade etmektedir. Örgütsel mizah "birinin (bir çalışanın) başka bir kişiyi eğlendirmek amacıyla paylaştığı ve bu diğer kişinin kasıtlı bir davranış olarak algılandığı herhangi bir olay” olarak tanımlanmaktadır (Cooper, 2005, s. 766-767). Romero and Cruthirds'e göre (2006, s. 59) ise örgütsel mizah "birey, grup ya da örgütte olumlu algılar ve duygular ortaya çıkartan eğlenceli haberleşmeler” olarak tanımlanmaktadır. Bu tanımdan hareketle Dikkers vd. (2012, s. 76) örgütsel mizahın; "birey, grup veya örgütte eğlence amacıyla gerçekleştirilen ve iş ilişkilerinde paylaşılan ciddiyet taşımayan uyuşmazlıklar” anlamına geldiğini söylemektedir. Liu ve Wang (2016, s. 1308) ise örgütsel mizahı, "bazı durumlarda, örgüt üyelerinin örgütsel iklimi düzenlemek amacıyla diğerlerinin duygusal ve bilişsel faaliyetlerini etkilemek için gerçekleştirdikleri yeni ve ilginç iletişim davranışları" olarak tanımlamaktadır. Romero ve Pescosolido, (2008, s. 397) başarılı bir örgütsel mizahın sadece yenilik değil aynı zamanda kabul edilebilir bir çeşitlilik içermesi de gerektiğini belirtmektedir.

Örgütsel mizah, mizahi unsurlardan türemiştir. Bu nedenle farklı bir iletişim aracı olması ve olumlu etkilerinin bulunması gibi mizaha ilişkin özellikler örgütsel mizah için de geçerlidir. 
Fakat örgütsel mizahın kendine özgü özellikleri de bulunmaktadır. Öncelikle farklı örgütlerin farklı örgüt kültürlerine sahip olması nedeniyle örgütler içerisinde mizah türü de farklılaşmaktadır. İkincisi örgütsel mizah örgüt ikliminin düzenlenmesi için bir araçtır. Pozitif örgütsel mizah işletmeler için yalnızca iyi bir örgüt iklimi oluşturmada değil, aynı zamanda kendi gelişimlerini teşvik etmede de yardımcı olabilmektedir (Liu ve Wang, 2016, s. 1308). Bunun yanında örgütsel mizahın olumsuz yönü de olabilmektedir. Alay etmek ve iğnelemek amacıyla gerçekleştirilen şakalar örgütsel etkinlik üzerinde olumsuz sonuçlar doğurabilmektedir (Decker vd., 2011, s. 45).

\section{Olumlu-Olumsuz Mizah Kullanımı}

İnsanlar isteyerek veya bilmeden bir şekilde mizahı kullanmaktadır. Bununla birlikte her insan birbirinden farklıdır ve bu farklılık mizah yapışşeklinde de farklılık meydana getirmektedir. Dolayısıyla mizah tarzları denildiğinde, insanların mizahı kullanma yolları belirtilmektedir (Martin vd., 2003).

Araştırmalarda mizah tarzlarının farklı sınıflamalara tabi tutulduğu görülmektedir. Duncan vd. (1990) mizah tarzlarını olumlu ve olumsuz şeklinde ikili bir ayrıma tabi tutmuştur. Bu ayrımda olumsuz mizah tarzı, diğer bir insan üzerinde zafer hissine odaklanmaktadır. Diğer bir ifadeyle, olumsuz mizah tarzı, insanların diğer insanlar üzerinde üstünlük sağladıklarında gülmesidir. Olumlu mizah tarzı ise, akılcı dil veya davranış kalıplarının kasıtlı olarak ihlali anlamına gelmektedir. Bu tarz da gülme, beklenmedik, belirsiz, mantıksız veya uygunsuz durumlarla ilişkilidir (Duncan vd., 1990, s. 258-260).

Mizah tarzlarına ilişkin literatürde en çok kabul göre ayrım ise Martin vd. (2003) tarafından gerçekleştirilmiştir. Martin vd., (2003) mizah tarzlarına ilişkin 2 X 2 modelini geliştirmiştir. Bu kapsamda mizah tarzları ikisi olumlu ikisi olumsuz olmak üzere dörtlü bir ayrıma tabi tutulmaktadır. Martin vd. (2003) olumlu mizah tarzlarının; katılımcı mizah ve kendini geliştirici mizah olduğunu belirtmektedir. Olumsuz mizah tarzları ise kendini yıkıcı mizah ve saldırgan mizah olarak isimlendirilmektedir.

Gerçekleştirilen ampirik araştırmaların bulguları, olumlu mizah tarzlarının psikolojik sağlık üzerinde olumlu etki yaratarak mutluluğu arttırdığına, olumsuz mizah tarzlarının ise huzursuzluğa yol açtığına dair önemli kanıtlar oluşturmaktadır. Özellikle katılımcı mizah tarzının daha fazla kullanımı mutluluğu arttıran sosyal destek ağlarının gelişimini ve sürdürülmesini kolaylaştırabilmektedir. Alternatif olarak, kendini yıkıcı mizah tarzının daha fazla kullanılması, psikolojik sağlı üzerinde olumsuz etkisi bulunan uyumsuz sosyal destek ağlarının gelişmesine yol açabilmektedir.

Bunun yanında iş hayatında ve örgütsel psikoloji araştırmalarında mizah tarzlarının kullanımı nadiren araştırılan bir konu durumundadır. Üstelik, sosyal-bireysel boyutlar açısından mizah tarzlarının örgütsel yaşam içerisinde incelenmesi gerekmektedir. 


\section{Olumlu-Olumsuz Mizah Kullanımı ile Çalışan Tutumları Arasındaki İlişki}

Çalışan tutumları kapsamında olumlu ve olumsuz mizah kullanımı ile iş tatmini, duygusal bağlılık ve algılanan örgütsel destek arasındaki ilişki incelenmektedir.

\section{Olumlu-Olumsuz Mizah Kullanımı ile İş Tatmini ilişskisi}

İş tatmini en genel şekilde "çalışanların işinden duyduğu memnuniyet ve mutluluk derecesi" anlamına gelmektedir (Hackman ve Oldham, 1975, s. 162). Bununla birlikte iş tatminine ilişkin farklı tanımların da yapıldığı görülmektedir. Locke (1976, s. 1304) iş tatminini, "bireyin işini ya da iş deneyimini değerlendirmesi sonucu ortaya çıkan memnun edici ve pozitif duygusal durum" olarak tanımlamaktadır. Luthans'a göre (1995, s. 171) ise iş tatmini "çalışanın gerçekleştirdiği işin kendisi için önemli olan değerleri ne derecede karşıladığına ilişkin algıladığ sonuç" anlamına gelmektedir.

Araştırmalar, olumlu mizahın yüksek iş tatmini ile büyük oranda ilişkili olduğunu ortaya koymaktadır (Wanzer vd., 2005; Hurren, 2006; Robert ve Yan, 2007; Mesmer Magnus vd., 2012; Batool vd., 2014; Robert vd., 2016). Bu çerçevede mizah, yapılan işin hem ilişkisel yönünü hem de görevle ilişkili yönünü olumlu şekilde etkileyebilmektedir (Robert ve Veiga, 2017).

Mesmer-Magnus vd. (2012) tarafından gerçekleştirilen ve 49 çalışma sonucunun derlendiği meta-analiz araştırması, çalışanların ve yöneticilerin mizah kullanımının çalışanların iş tatminleri üzerinde olumlu etkisi bulunduğunu göstermektedir. Çalışmada mizah kullanımı ve iş tatmini arasında orta düzeyde bir ilişki bulunduğu tespit edilmiştir. Bununla birlikte araştırma sonuçları ayrıca işinden memnun olan çalışanların mizah kullanımının memnun olmayanlara göre daha yüksek derecede olduğunu göstermektedir.

Hurren'in (2006) çalışması, okul müdürlerinin genel mizah kullanım sıklığının öğretmenler tarafından nasıl algılandığını ve okul müdürlerinin mizah kullanımının öğretmenlerin iş tatminleri üzerindeki etkisini araştırmaktadır. Çalışma farklı seviyelerdeki 471 öğretmen üzerinde gerçekleştirilmiştir. Çalışmanın sonuçları, işyerinde mizah kullanımı yüksek olan müdürlerin, mizahı az kullanan veya hiç kullanmayan müdürlere nazaran çok daha fazla işinden memnun öğretmenlere sahip olduğunu göstermektedir.

Benzer bir araştırma da Recepoğlu (2008) tarafından gerçekleştirilmiştir. Araştırma ile okul müdürlerinin öğretmenler tarafından algılanan mizah yeteneklerini kullanma sıklığı ve müdürlerin mizah yeteneklerini kullanmalarının öğretmenlerin iş tatminine etkisi incelemektedir. Araştırmanın bulguları, öğretmenlerin iş tatmini üzerinde okul müdürlerinin mizah yeteneğinin önemli bir role sahip olduğunu göstermektedir.

Cann vd. (2014) araştırmasında mizahın dört türünün (olumlu mizah, olumsuz mizah, grup dışı mizah ve yönetici desteği sağlayan mizah) örgütsel sonuçlarını araştırmaktadır. Araştırmanın sonuçları olumlu mizahın ve yönetici desteği sağlayan mizahın iş tatmini üzerinde pozitif yönlü etkisinin bulunduğunu, grup dışı mizahın ise negatif yönlü bir etkisinin 
bulunduğunu göstermektedir. Buna karşılık araştırma bulgularına göre olumsuz mizah ile iş tatmini arasında anlamlı bir ilişki belirlenememiştir.

Sobral ve Islam (2015) tarafından gerçekleştirilen araştırma ile mizahın olumlu ve olumsuz şekilde kullanımı ile iş tatmini arasındaki ilişki araştırılmaktadır. Araştırma Brezilya'da gerçekleştirilmiş ve araştırmanın örneklemi 184 stajyerden oluşmaktadır. Araştırmanın sonucunda olumlu mizahın iş tatminini pozitif yönde etkilediği ve olumsuz mizahın ise iş tatminini negatif yönde etkilediği belirlenmiştir. Elde edilen bulgular olumsuz mizahın olumlu mizaha göre iş tatmini üzerinde daha güçlü bir etkiye sahip olduğunu göstermektedir.

Genel olarak literatür incelendiğinde mizah ile iş tatmini arasında olumlu bir ilişki bulunduğu gözlenmektedir. Diğer bir ifadeyle araştırmalarda, mizah kullanımının çalışanların iş tatminini arttıran bir faktör olduğu belirtilmektedir. Bununla birlikte araştırmalarda daha çok iş tatmini üzerinde olumlu mizahın etkisinin araştırıldığı ve olumsuz mizah kullanımının iş tatmini üzerindeki etkisine odaklanan sınırlı sayıda çalışmanın bulunduğu görülmektedir.

Gerçekleştirilen araştırmalardan elde edilen bulgular sonucunda çalışmanın ilk hipotezi aşağıdaki şekilde oluşturulmuştur.

H1: Yöneticilerin mizah kullanımı ile çalışanların iş tatmini arasında anlamlı bir ilişki vardır. H1a: Yöneticilerin olumlu mizah kullanımı arttıkça çalışanların iş tatmini seviyeleri artmaktadır.

H1b: Yöneticilerin olumsuz mizah kullanımı arttıkça çalışanların iş tatmini seviyeleri azalmaktadir.

\section{Olumlu-Olumsuz Mizah Kullanımı ile Duygusal Bağlılık iliş̧kisi}

Örgütsel bağlllık en genel şekilde "bireyi örgüte bağlayan psikolojik durum" (Allen ve Meyer, 1990, s. 14) veya "çalışanın örgütüne bağlanması ve kendisini adaması" (Taşçı vd., 2016, s. 131) şeklinde tanımlanmaktadır. Diğer bir tanım çerçevesinde ise örgütsel bağllık, "bireyin kurumsal amaç ve değerleri kabul etmesi, bu amaçlara ulaşılması yönünde çaba sarf etmesi ve kurum üyeliğini devam ettirme arzusu" olarak ifade edilmektedir (Durna ve Eren, 2005, s. 211). Dolayısıyla örgütsel bağllılk denildiğinde örgüt ile birey arasındaki ilişkinin ortaya konduğu temel unsurdan bahsedilmektedir (Sığrı, 2007, s. 262).

Örgütsel bağlllığa ilişkin çalışmalarda genel olarak üç konuya değinildiği görülmektedir. Bunlar; çalışanın örgütüyle kurduğu duygusal bağ (duygusal bağlllık), çalışanın örgütünden ayrılması durumunda ortaya çıkan maliyetler (devam bağlllı̆ı) ve çalışanın örgütünde devam etmesine neden olan yükümlülüklerdir (normatif bağlllık). Bu çerçevede genel olarak örgütsel bağllıık kavramı üç boyut kapsamında incelenmektedir (Allen ve Meyer, 1990; Meyer ve Allen, 1991).

Örgütsel bağlllık her ne kadar üç boyutta incelenen bir kavram olsa da, asıl bağlllı̆̆ın çalışanın duygusal olarak örgütüyle bütünleşmesi, örgütünde çalışmaktan mutluluk duyması olduğu düşünülmektedir (Allen ve Meyer, 1990). Bununla birlikte tutum ve davranışlar üzerinde duygusal bağlllığın diğer boyutlara nazaran çok daha güçlü bir etkisinin bulunduğu 
belirlenmiştir (Meyer, vd., 2002). Bu nedenle duygusal bağlllık için örgütsel bağlllığın temel boyutu olduğu söylenebilmektedir. Dolayısıyla örgütsel bağllık denildiğinde çoğu zaman duygusal bağlılık anlaşılmaktadır.

Araştırmalara göre, örgütsel bağlılık üzerinde özellikle de duygusal bağlılık üzerinde etkili olan faktörlerden birinin de olumlu mizah kullanımı olduğunu söylemek mümkündür. Çünkü çalışanların örgütlerine bağlanmasında etkili olan faktörlerden biri de bireyler arasında kurulan arkadaşlık ilişkileridir. Bireyler arasındaki mizah paylaşımı da iletişimi kolaylaştırmakta ve güçlendirmektedir (Adıgüzel vd., 2014:14). İşyerinde eğlencenin etkileri üzerine gerçekleştirilen araştırmalarda, olumlu mizah kullanımının birçok olumlu etkisinden birinin de çalışanların bağlılığını arttırması olduğu belirlenmiştir (Hughes ve Avey, 2009; Romero ve Arendt, 2011; Adıgüzel vd., 2014; Cann vd., 2014). Bu çerçevede bireyler arasında eğlence ve gülmeye neden olan mizahi davranışların örgüte olan duygusal bağlılığı ve örgütsel değerlere olan inancı arttırdığını söylemek mümkündür.

Kişisel mizah tarzları ile farklı örgütsel değişkenler arasındaki ilişkiyi araştıran Romero ve Arendt (2011), kullanılan mizah tarzının (katılımcı mizah, kendini geliştirici mizah, kendini yıkıcı mizah ve saldırgan mizah) çalışan tutum ve davranışları üzerinde ne tür bir etkiye sahip olduğunu belirlemeye çalışmaktadır. Araştırma küçüklü büyüklü farklı örgütlerde çalışmakta olan 349 işgören üzerinde gerçekleştirilmiştir. Araştırmanın sonucunda, çalışanların örgütlerine bağlılıkları üzerinde katılımcı mizahın ve kendini geliştirici mizahın pozitif yönlü bir etkisinin bulunduğu belirlenmiştir. Diğer taraftan saldırgan mizah ise örgütsel bağlılığ1 negatif olarak etkilemektedir. Buna karşılık kendini yıkıcı mizah ile örgütsel bağlılık arasında anlamlı bir ilişki tespit edilememiştir.

Cann vd. (2014) ise çalışanlar tarafından kullanılan farklı mizah tarzları (olumlu mizah, olumsuz mizah, grup dışı mizah ve yönetici desteği sağlayan mizah) ile çeşitli çalışan tutumları arasındaki ilişkiyi incelemektedir. Bu çerçevede mizah tarzlarının duygusal bağlılık üzerindeki etkisi de incelenmektedir. Çalışmanın sonucunda, duygusal bağlılık üzerinde olumlu mizahın ve yönetici desteği sağlayan mizahın pozitif yönlü bir etkisinin bulunduğu, grup dışı mizahın ise negatif yönlü bir etkisinin bulunduğu belirlenmiştir. Olumsuz mizahın ise duygusal bağlılık üzerinde bir etkisi tespit edilememiştir.

Gerçekleştirilen araştırmalardan elde edilen bulgular sonucunda çalışmanın ikinci hipotezi aşağıdaki şekilde oluşturulmuştur.

H2: Yöneticilerin mizah kullanımı ile çalışanların duygusal bağlılığı arasında anlamlı bir ilişki vardir.

H2a: Yöneticilerin olumlu mizah kullanımı arttıkça çalışanların duygusal bağlılık seviyeleri artmaktadir.

H2b: Yöneticilerin olumsuz mizah kullanımı arttıkça çalışanların duygusal seviyeleri azalmaktadır. 


\section{Olumlu-Olumsuz Mizah Kullanımı ile Lider-Üye Etkileşimi İlişkisi}

Lider-üye etkileşimi, lider ile belirli bir takipçi arasındaki profesyonel ilişkinin kalitesi olarak tanımlanmaktadır (Graen ve Uhl-Bien, 1995, s. 227). Lider-üye etkileşimi teorisi, liderlerin tüm astları ile ilişkilerinde aynı tarzı kullanmadığını, aksine her bir takipçiyle farklı bir ilişki veya etkileşim türü geliştirdiğini öne sürmektedir (Liden ve Maslyn, 1998, s. 43). Bu çerçevede, liderler astlarına onları grup içi (yüksek kaliteli ilişki) veya grup dışı (düşük kaliteli ilişki) görmelerine bağlı olarak farklı muamele gösterebilmektedir. Çünkü lider-üye etkileşimi teorisine göre, yöneticilerin kısıtlı zamana ve kaynağa sahip olması nedeniyle tüm astları ile eşit olarak etkileşmesi imkansızdır (Graen ve Scandura, 1987, s. 182). Lider ile üye arasında yüksek kalitede bir ilişki, yüksek düzeyde güven, saygı ve karşılıklı yükümlülük ile nitelendirilmektedir (Graen ve Uhl-Bien, 1995, s. 227).

Araştırmalar, liderin mizah kullanımının ve mizah tarzının lider ile üye arasındaki etkileşimin gelişimine katkıda bulunduğunu ileri sürmektedir (Gkorezis vd., 2014; Wisse ve Rietzschel, 2014; Pundt ve Herrmann, 2015). Cooper (2008) liderin olumlu mizah kullanmasının pozitif ilişkilerin gelişimi için çok önemli olan ilişkisel süreçler üzerinde olumlu etkiler sağlayacağını belirtmektedir. Lider-üye etkileşimi de bu önemli ilişkisel süreçlerden biridir. Dolayısıyla mizah, genel olarak olumlu ilişkilerin gelişmesi için önemli bir koşul olarak kabul edilmektedir ve mizahi insanların sosyal ilişkileri başlatmasının ve sürdürmesinin daha kolay olduğu düşünülmektedir (Hampes, 2005; Martin, 2007).

Pundt ve Herrmann (2015) tarafından gerçekleştirilen araştırma yöneticiler tarafından kullanılan katılımcı ve saldırgan mizah tarzları ile lider-üye etkileşimi arasındaki ilişkiyi belirlemeye çalışmaktadır. Araştırmada kullanılan veri altı hafta arayla gerçekleştirilen iki farklı anket çalışması aracılığıyla Almanya'da farklı işletmelerde çalışan 152 kişiden elde edilmiştir. Araştırmanın sonucunda lider-üye etkileşimi ile katılımcı mizahın pozitif yönlü ve saldırgan mizahın negatif yönlü ilişkisi bulunduğu belirlenmiştir.

Mizah kullanımının lider ve takipçi arasındaki ilişkinin kalitesini (lider-üye etkileşimi) nasıl etkilediğine odaklanan bir araştırma da Wisse ve Rietzschel (2014) tarafından gerçekleştirilmiştir. Çalışmanın amacı, çalışanların kullandığı mizah tarzlarının ve liderlerin kullandığı mizah tarzlarının lider-üye etkileşimi üzerindeki etkisini belirleyebilmektir. Çalışma Hollanda'da farklı sektörlerdeki 88 lider ve onların 257 çalışanı üzerinde gerçekleştirilmiştir. Çalışmanın sonucunda, genel olarak lider-üye etkileşimi üzerinde çalışanların katılımcı mizah tarzının olumlu ve çalışanların saldırgan mizah tarzının ise olumsuz etkiye sahip olduğu belirlenmiştir.

Araştırmalar, mizahın lider ve takipçi arasındaki lider-üye etkileşiminin kalitesini arttırma potansiyeli olduğunu göstermektedir. Fakat tüm mizah tarzları, insanlar arasındaki etkileşimin memnuniyetini ve kalitesini arttırmaya eşit derecede yardımcı olmayabilmektedir (Martin vd., 2003). Mizah aynı zamanda utandırma, hakaret etme ve küçük düşürme amacını da güdebilmektedir (Martin, 2007; Kuiper ve Harris, 2009). Bu çerçevede olumsuz mizah tarzı ile lider üye etkileşimi arasında negatif bir ilişki öngörülmektedir. Çünkü bu mizah türü diğer 
insanlarla alay etmek ve dalga geçmek amacıyla, hataları için insanları eleştirmek ve kızdırmak amacıyla ve en genel şekilde insanları bastırmak amacıyla kullanılabilmektedir. Örgüt içinde bu tür mizah kullanımı ilişkilere zarar verebilir ve bu tür mizah kullanan insanlar, mizahın diğer insanlar üzerindeki yaralayıcı etkilerini dikkate almamaktadır. Dolayısıyla liderin olumsuz mizah kullanması durumunda takipçilerin liderle olumlu ilişkiler kurması daha az olasıdır (Pundt ve Herrmann, 2015:111).

Gerçekleştirilen araştırmalardan elde edilen bulgular sonucunda çalışmanın üçüncü hipotezi aşağıdaki şekilde oluşturulmuştur.

H3: Yöneticilerin mizah kullanımı ile çalışanların lider-üye etkileşimi algıları arasında anlamlı bir ilişki vardır.

H3a: Yöneticilerin olumlu mizah kullanımı arttıkça çalışanların lider-üye etkileşimi algıları artmaktadir.

H3b: Yöneticilerin olumsuz mizah kullanımı arttıkça çalışanların lider-üye etkileşimi algıları azalmaktadir.

Çalışma kapsamında yöneticilerin mizah kullanımı ile çalışanların iş tatmini, duygusal bağlılık ve lider-üye etkileşimi algıları arasındaki ilişki araştırılmaktadır. Bu kapsamda, test edilmek istenen hipotezlerin yer aldığı araştırma modeli Şekil 1'de gösterilmektedir.

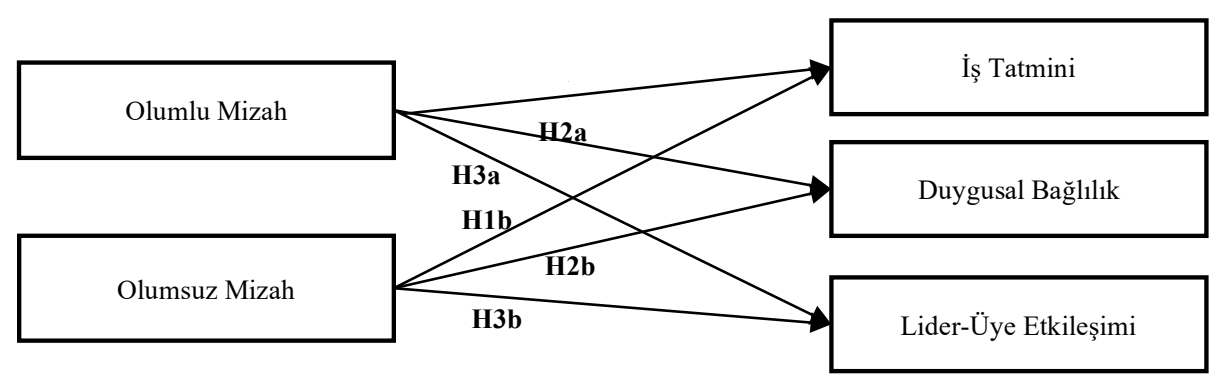

Şekil 1. Araştırma Modeli

\section{Araştırma Yöntemi}

\section{Araştırmanın Ana Kütlesi ve Örneklemi}

$\mathrm{Bu}$ çalışmanın odak noktası farklı sektörlerdeki yöneticiler ve onların çalışanlarıdır, fakat veriler çalışanlardan elde edilmiştir. Diğer bir ifadeyle, veriler, çalışanların bakış açısından yöneticilerini ve kendi tutumlarını değerlendirmesi ile sağlanmıştır. Bu çerçevede, araştırmanın ana kütlesi, Karabük Üniversitesi Sosyal Bilimler Enstitüsü’nde öğrenim gören ve bir özel veya kamu kurumunda çalışmakta olan lisansüstü öğrencilerinden oluşmaktadır. Kurumdan alınan bilgilere göre Nisan 2018 yılı itibariyle Enstitüde toplam 1669 öğrenci öğrenim görmekte ve bu öğrencilerin 975 tanesi bir özel veya kamu kurumunda görev yapmaktadır. Dolayısıyla araştırmanın ana kütle toplam 975 kişiden oluşmaktadır. Sekaran ve Bougie (2016, s. 264), 975 
kişiden oluşan bir ana kütleyi temsil eden en küçük örneklem büyüklüğünü 278 olarak hesaplamıştır. Bu çerçevede, toplam 927 kişinin mail adresine ulaşılmış ve anket formu internet ortamında hazırlanarak ve kolayda örnekleme yönetimi kullanılarak 927 kişiye gönderilmiştir. Anket formu çeşitli aksaklıklar nedeniyle 13 kişiye ulaştırılamamıştır. Dolayısıyla toplamda 914 kişinin anket formunu gördüğü düşünülmektedir.

Katılımcıların 152'inden geri dönüş sağlanmış ve geri dönüş oranı $\% 16$ olarak hesaplanmıştır. Örneklem büyüklüğünün yetersiz olması nedeniyle eğitim-öğretim dönemi sırasında daha önce anketi doldurmamış katılımcılara anketler dağıtılıış ve bu süreçte toplam 185 kişinin katılımı sağlanmıştır. İncelenen anketlerin 12 tanesinin geçersiz olduğu belirlenmiştir. Geçersiz sayılan cevaplar analiz dışında bırakılmıştır. Sonuç olarak araştırmanın örneklemi 325 kişiden oluşmaktadır.

\section{Araştırmanın Veri Toplama Aracı, Kullanılan Ölçekler ve Analiz Yöntemi}

Analizlerde kullanılan verinin elde edilmesinde online anket tekniği kullanılmıştır. Bu çerçevede oluşturulan anket formu üç bölümden meydana gelmiştir. İlk bölümde, yöneticilerin olumlu ve olumsuz mizah kullanımının katılımcılar tarafından ne şekilde algılandığını belirlemeye yönelik hazırlanan 7 ifade bulunmaktadır. İkinci bölümde, katılımcıların iş tatmini derecesini belirlemek için 5 ifade, duygusal bağlllık derecesini belirlemek için 6 ifade ve liderüye etkileşimi algıları derecesini belirlemek için 7 ifade yer almaktadır. Üçüncü bölümde ise, yaş, cinsiyet, medeni durum, çalışma süresi ve çalışlan sektör gibi katılımcıların tanımlayıcı bilgilerini belirlemeye yönelik hazırlanan sorular vardır.

$\mathrm{Bu}$ çerçevede, araştırmada dört farklı ölçekten faydalanılmıştır. Çalışanlar tarafından algılanan olumlu ve olumsuz mizah kullanım derecesini belirleyebilmek için Decker ve Rotondo (2001) tarafından geliştirilmiş olan Yönetici Mizah Ölçeği kullanılmıştır. Ölçek Büyükyılmaz’nn (2018) çalışmasından adapte edilerek araştırmada kullanılmıştır. Ölçek, yöneticilerin olumlu ve olumsuz mizahı ne derece kullandığının çalışanlar tarafından nasıl algılandığını ölçmek amacıyla hazırlanmıştır. Ölçek toplam yedi ifadeden oluşmaktadır ve beş ifade yöneticinin olumlu mizah kullanım derecesini, iki ifade ise olumsuz mizah kullanım derecesini ölçmek amacıyla kullanılmaktadır. Decker ve Rotondo (2001) ölçeğin Cronbach alfa güvenilirlik değerinin olumlu mizah için 0,86 ve olumsuz mizah için 0,82 olduğunu tespit etmiş̧ir.

Çalışanların genel iş tatmini derecelerini ölçmek için Hackman ve Oldham'ın (1975) İş Özellikleri Anketi'nden Basım ve Şeşen (2009) tarafından uyarlanan ölçek kullanılmıştır. İş tatmini ölçeği Şeşen'in (2010) çalışmasından adapte edilerek araştırmada kullanılmıştır. Ölçek tek boyuttan oluşmakta ve ölçek içerisinde beş ifade bulunmaktadır. Basım ve Şeşen (2009) ölçeğin Cronbach alfa güvenilirlik değerini 0,78 olarak tespit etmiştir. Şeşen (2010) ise çalışmasında güvenilirliği 0,84 olarak hesaplamıştır.

Çalı̧anların örgütlerine karşı duygusal bağlllık derecelerini tespit edebilmek için Allen ve Meyer (1990) tarafından geliştirilen, daha sonra Meyer vd. (1993) tarafından revize edilen ölçek kullanılmıştır. Duygusal bağlllık ölçeği, örgütsel bağlllık ölçeği içerisinde yer alan üç alt ölçekten 
biridir. Duygusal bağlılık ölçeği, tek boyuttan ve altı ifadeden oluşmaktadır. Ölçeğin Türkçe uyarlaması, Gürkan (2006) tarafından gerçekleştirilen çalışmadan revize edilerek anket formuna dahil edilmiştir. Meyer vd. (1993) gerçekleştirdiği çalışmada ölçeğin Cronbach alfa güvenilirlik değerini 0,87 ve 0,85 olarak belirlemiştir. Gürkan'ın (2006) çalışmasında ise Cronbach alfa güvenilirlik değeri 0,75 olarak tespit edilmiştir.

Çalışanların lider-üye etkileşimi algılarının derecesi ise Scandura ve Graen (1984) tarafından geliştirilen lider-üye etkileşimi üye (LMX-7 Member) ölçeği ile belirlenmiştir. Lider-üye etkileşimi ölçeği tek boyuttan ve yedi ifadeden meydana gelmiş bir ölçektir. Ölçeğin Türkçe uyarlaması, Özutku vd. (2008) ile Karcıoğlu ve Kahya (2011) tarafından gerçekleştirilen çalışmadan revize edilerek anket formuna dahil edilmiştir. Scandura ve Graen (1984) gerçekleştirdiği çalışmada ölçeğin Cronbach alfa güvenilirlik değerini 0,86 ve 0,84 olarak belirlemiştir. Özutku vd. (2008) çalışmasında Cronbach alfa güvenilirlik değerini 0,73 olarak ve Karcıoğlu ve Kahya (2011) ise çalışmasında Cronbach alfa güvenilirlik değerini 0,88 olarak tespit etmiştir.

Katılımcılardan ankette bulunan ifadelere hangi oranda katıldıklarını Likert tipi 5'li ölçek üzerinde "1-Hiç katılmıyorum” ile “5-Tamamen Katılıyorum” şeklindeki sıklık aralığında işaretlemeleri istenmektedir. Ölçeklerden elde edilen yüksek skorların yükselmesi ilgili değişkene ilişkin algının yüksek olduğunu göstermektedir.

Çalışmada kullanılan ölçekler için yapı geçerliliği faktör analizi ile araştırılmıştır. Çalışmada bağımsız değişken olarak kullanılan ve yöneticilerin olumlu ve olumsuz mizah kullanımını belirlemeyi amaçlayan yönetici mizah ölçeği, Büyükyılmaz (2018) tarafından gerçekleştirilen çalışmadan adapte edilmiştir. Ölçeğin Türkçe formuna ilişkin daha önce geçerlilik ve güvenilirlik analizi yapılmamıştır. Bu nedenle, çalışma kapsamında yönetici mizah ölçeğinin Türkçe formuna ilişkin yapı geçerliliği açıklayıcı faktör analizi ile test edilmiştir. Çalışmada kullanılan diğer ölçeklerin (iş tatmini ölçeği, duygusal bağlılık ölçeği, lider-üye etkileşimi ölçeği) ise farklı yerli ve yabancı çalışmalarda sıklıkla kullanıldığı, bu çalışmalarda tek faktörlü yapılarına ilişkin geçerliliğin ve güvenilirliğin sağlandığı belirlenmiştir. Bu nedenle belirtilen üç ölçeğin yapı geçerliliğinin araştırılmasında doğrulayıcı faktör analizi kullanılmıştır. Açıklayıcı ve doğrulayıcı faktör analizlerinden sonra ölçeklere güvenilirlik analizleri uygulanmıştır. Ölçek güvenilirlikleri Cronbach alfa (a) güvenilirlik değeri ve birleşik güvenilirlik değeri ile belirlenmeye çalışılmıştır.

Çalışmada test edilmek istenilen hipotezler ise hiyerarşik regresyon analizi ile araştırılmıştır. Doğrulayıcı faktör analizi AMOS programı ile, açıklayıcı faktör analizi, güvenilirlik analizleri ve hiyerarşik regresyon analizi ise SPSS programı ile gerçekleştirilmiştir. 


\section{Bulgular}

\section{Demografik Özellikler}

Katılımcıların demografik özellikleri kapsamında cinsiyete, medeni duruma, yaşa, çalışma süresine ve çalışlan sektöre ilişkin bilgiler incelenmektedir. Demografik özelliklere göre dağılım Tablo 1'de gösterilmektedir.

Tablo 1. Katılımcıların Demografik Bilgileri

\begin{tabular}{|c|c|c|c|}
\hline Değişken & Kategori & Sayı & Yüzde \\
\hline \multirow{2}{*}{ Cinsiyet } & Kadın & 154 & 47,4 \\
\hline & Erkek & 171 & 52,6 \\
\hline \multirow{2}{*}{$\begin{array}{l}\text { Medeni } \\
\text { Durum }\end{array}$} & Evli & 176 & 54,2 \\
\hline & Bekar & 149 & 45,8 \\
\hline \multirow{4}{*}{$\begin{array}{c}\text { Yaş } \\
(\text { Ort. }=29,7)\end{array}$} & $\begin{array}{l}25 \text { yaş ve } \\
\text { altı }\end{array}$ & 54 & 16,7 \\
\hline & $\begin{array}{l}26-30 \text { yaş } \\
\text { arası }\end{array}$ & 146 & 44,9 \\
\hline & $\begin{array}{l}\text { 31-35 yaş } \\
\text { arası }\end{array}$ & 84 & 25,8 \\
\hline & $\begin{array}{l}36 \text { yaş ve } \\
\text { üstü }\end{array}$ & 41 & 12,6 \\
\hline \multirow{4}{*}{$\begin{array}{c}\text { Çalışma } \\
\text { Süresi } \\
(\text { Ort. }=5,5)\end{array}$} & 1 yıl ve altı & 52 & 16,0 \\
\hline & $2-5$ yıl arası & 125 & 38,5 \\
\hline & $\begin{array}{l}6-10 \quad \text { yıl } \\
\text { arası }\end{array}$ & 104 & 32,0 \\
\hline & $\begin{array}{l}11 \text { yıl ve } \\
\text { üstü }\end{array}$ & 44 & 13,5 \\
\hline \multirow{2}{*}{ Sektör } & Kamu & 141 & 43,4 \\
\hline & Özel & 184 & 56,6 \\
\hline
\end{tabular}

Tablo 1 incelendiğinde araştırmaya daha çok erkek $(\% 52,6)$ ve evli $(\% 54,2)$ çalışanların katılım gerçekleştirdiği görülmektedir. Katılımcıların çoğunluğunun 26-30 yaş arasında $(\% 44,9)$ olduğu görülmekte ve yaş ortalaması 29,7'dir. Çalışma süresi incelendiğinde katılımcıların çoğunluğunun 2-5 yıl arasında $(\% 38,5)$ kurumlarında çalışmakta olduğu ve ortalama çalışması süresinin 5,5 yıl olduğu belirlenmiştir. Yine araştırmaya katılanların çoğunluğu özel sektör çalışanıdır $(\% 56,6)$.

\section{Normallik Analizi}

Analizler öncesinde değişkenlerin parametrik testlere uygunluğunun belirlenmesi amacıyla normal dağılım testi gerçekleştirilmiştir. Değişkenlerin normalliği, istatistiksel veya grafiksel yöntemlerle değerlendirilebilmektedir. Normal dağılımın iki bileşeni olarak çarpıklık ve basıklık değerleri gösterilmektedir (Tabachnick ve Fidell, 2013). Bu çerçevede, araştırma kapsamında normal dağılım çarpıklık ve basıklık değerleri kapsamında incelenmiştir. 
Tabachnick ve Fidell (2013, s. 79) değişkenlerin normal dağılım şartını sağlaması için çarpıklık ve basıklık değerlerinin $+1,5$ ile $-1,5$ arasında olması gerektiğini belirtmektedir. Araştırmada kullanılan değişkenlere ilişkin hesaplanan çarpıklık ve basıklık değerleri Tablo 2'de gösterilmektedir.

Tablo 2. Normal Dağılım Testi

\begin{tabular}{|l|c|c|}
\hline Değişken & Çarpıklık & Basıklık \\
\hline Olumlu Mizah & $-0,421$ & $-0,458$ \\
\hline Olumsuz Mizah & 0,493 & $-0,511$ \\
\hline İş Tatmini & $-0,240$ & 0,389 \\
\hline Duygusal Bağıııı & $-0,079$ & 0,159 \\
\hline Lider-Üye Etkileşimi & $-0,212$ & 0,623 \\
\hline
\end{tabular}

Tablo 2 incelendiğinde hem çarpıklık hem de basıklık değerlerinin $+1,5$ ile $-1,5$ arasında olduğu görülmektedir. $\mathrm{Bu}$ bulguya göre araştırma kapsamında kullanılan değişkenlerin normal dağılıma sahip olduğu söylenebilmektedir.

\section{Geçerlilik Analizi}

Araştırmada geçerlilik analizleri, bağımlı ve bağımsız değişkenler için ayrı ayrı gerçekleştirilmiştir. Araştırmanın bağımlı değişkeni olan yönetici mizah ölçeğinin yapı geçerliliğini ve boyutsal yapısını belirleyebilmek için ölçek içerisindeki 7 ifadeye açıklayıcı faktör analizi uygulanmıştır. Analiz sonucunda ölçeğin iki faktörlü yapısının bulunduğu belirlenmiştir, fakat "Yöneticim, mizahı saldırgan olmayan şekilde kullanır" şeklindeki ifadenin her iki faktör içerisinde de 0,50'den yüksek bir faktör yüküne sahip olduğu gözlemlenmiştir. Bu nedenle belirtilen ifade analizden çıkartılarak faktör analizi tekrarlanmıştır (Brown, 2015, s. 32). Yönetici mizah ölçeği kapsamında 6 ifade ile gerçekleştirilen açıklayıcı faktör analizi sonuçları Tablo 3'de sunulmaktadır. 
Tablo 3. Yönetici Mizah Ölçeği Açıklayıcı Faktör Analizi Sonuçları

\begin{tabular}{|c|c|c|}
\hline \multirow[b]{2}{*}{ Ölçek ífadeleri } & \multicolumn{2}{|c|}{ Faktör } \\
\hline & $\begin{array}{l}\text { Olumlu } \\
\text { Mizah }\end{array}$ & $\begin{array}{c}\text { Olumsuz } \\
\text { Mizah }\end{array}$ \\
\hline $\begin{array}{l}\text { 2. Yöneticim, mizah yoluyla iletişim } \\
\text { kurar. }\end{array}$ & 0,783 & 0,095 \\
\hline 3. Yöneticim, şaka yapmaktan hoşlanır. & 0,741 & 0,037 \\
\hline $\begin{array}{l}\text { 1. Yöneticimin iyi bir espri anlayışı } \\
\text { vardır. }\end{array}$ & 0,728 & 0,111 \\
\hline 4. Yöneticim, fıkra anlatmayı sever. & 0,638 & 0,186 \\
\hline 6. Yöneticim cinsiyetçi şakalar yapar. & 0,078 & 0,964 \\
\hline $\begin{array}{l}\text { 7. Yöneticim, mizahı aşağılamak için } \\
\text { kullanır. }\end{array}$ & 0,283 & 0,673 \\
\hline KMO Uygunluk Ölçütü & \multicolumn{2}{|c|}{0,845} \\
\hline Barlett Küresellik Testi & \multicolumn{2}{|c|}{$\chi 2=557,918, s d=15, p=0,001$} \\
\hline Özdeğerler & 3,105 & 1,027 \\
\hline Varyans Açıklama Oranı (\%) & 51,747 & 12,256 \\
\hline Kümülatif Varyans Açıklama Oranı (\%) & 51,747 & 64,002 \\
\hline
\end{tabular}

Açıklayıcı faktör analizinde Temel Bileşenler Analizi yöntemi kullanılmıştır ve döndürme işlemi Direct Oblimin yöntemi ile gerçekleştirilmiştir (Hair vd., 2014, s. 114; Brown, 2015, s. 27-30). Analizde yönetici mizah ölçeğinin örneklem yeterliliğinin belirlenmesi için KMO uygunluk ölçütüne ve örneklem büyüklüğünün yeterliliği için ise Barlett Küresellik Testine bakılmıştır. Analiz sonucunda KMO değeri 0,845 olarak hesaplanmış ve dolayısıyla bu değerin 0,70’in üzerinde olması açıklayıcı faktör analizi için örneklemin yeterli olduğunu göstermiştir. Barlett küresellik testi sonucunda ise $\chi 2$ değerinin anlamlı olduğu tespit edilmiştir ve bu sonuç verilerin faktör analizine uygun olduğunu göstermektedir.

Yönetici mizah ölçeğinin kaç boyuttan oluştuğuna karar vermek için özdeğerlere bakılmış ve özdeğerleri 1'den büyük olan faktörler boyut olarak kabul edilmiştir (Hair vd., 2014, s. 197; Brown, 2015, s. 23). Analiz ile özdeğerleri birden büyük olan iki faktör belirlenmiştir ve bu faktörler toplam değişkenliğin \%64,002'sini açıklamaktadır. Birinci faktör içerisinde yöneticilerin olumlu mizah kullanımına ilişkin ifadeler bulunmaktadır. Dolayısıyla bu faktör "olumlu mizah kullanımı" olarak isimlendirilmiştir. İkinci faktör içerisinde ise yöneticilerin olumsuz mizah kullanımına ilişkin ifadeler yer almaktadır. Bu nedenle ikinci faktöre "olumsuz mizah kullanımı” ismi verilmiştir.

Araştırmada kullanılan diğer ölçeklerin (iş tatmini, duygusal bağlılık, lider-üye etkileşimi) farklı çalışmalarda geçerliliklerinin sağlanması ve faktör yapılarının bu çalışmalar kapsamında belirlenmesi nedeniyle, bu ölçeklerin yapı geçerliliğini belirleyebilmek için doğrulayıcı faktör analizi tercih edilmiştir. Bu çerçevede belirtilen üç ölçeğin dahil edildiği ölçüm modelinin 
oluşturulmasıyla analiz gerçekleştirilmiştir. Doğrulayıcı faktör analizi ile elde edilen bulgular Tablo 4'de gösterilmektedir.

Model uyumunda ki kare uyum testi ( $\chi 2 / s d)$, uyum iyiliği indeksi (GFI), Tucker-Lewis indeksi (TLI), karşılaştırmalı uyum indeksi (CFI) ve yaklaşık hataların ortalama karekökü (RMSEA)

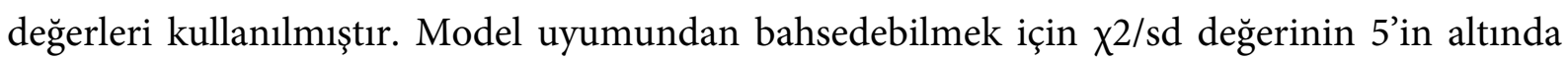
olması, GFI, TLI ve CFI değerlerinin 0,90'ın üstünde ve RMSEA değerinin 0,80'in altında olması beklenmektedir (Schumacker ve Lomax, 2010, s. 85-89; Meydan ve Şeşen, 2011, s. 31-37; Byrne, 2016, s. 90-102; Kline, 2016, s. 265-280).

Tablo 4. Bağımlı Değişkenler Doğrulayıcı Faktör Analizi Sonuçları

\begin{tabular}{|c|c|c|c|c|}
\hline $\begin{array}{l}\text { Ölçek } \\
\text { Maddeleri }\end{array}$ & $\begin{array}{l}\text { Faktör } \\
\text { Yükü }\end{array}$ & $\begin{array}{c}\text { Standart } \\
\text { Hata }\end{array}$ & $\begin{array}{c}\mathbf{t} \\
\text { değeri }\end{array}$ & $\begin{array}{c}\text { Uyum } \\
\text { İyiliği } \\
\text { Değerleri }\end{array}$ \\
\hline IŞTAT1 & $0,633^{* *}$ & - & - & \\
\hline işTAT2 & $0,630 * *$ & 0,125 & 8,610 & $\begin{array}{c}x 2= \\
218,404\end{array}$ \\
\hline işTAT3 & $0,540 * *$ & 0,123 & 7,685 & $s d=132$ \\
\hline IŞTAT4 & $0,496 * *$ & 0,114 & 7,170 & $\begin{array}{c}x^{2} / s d= \\
1,655\end{array}$ \\
\hline IŞTAT5 & $0,713 * *$ & 0,139 & 9,262 & $\mathrm{GFI}=0,912$ \\
\hline DUYGBAĞ1 & $0,574 * *$ & - & - & $T L I=0,920$ \\
\hline DUYGBAĞ2 & $0,581 * *$ & 0,145 & 7,541 & $C F I=0,931$ \\
\hline DUYGBAĞ3 & $0,417 * *$ & 0,134 & 5,909 & $\begin{array}{c}\text { RMSEA = } \\
0,045\end{array}$ \\
\hline DUYGBAĞ4 & $0,507 * *$ & 0,141 & 6,869 & \\
\hline DUYGBAĞ5 & $0,625 * *$ & 0,149 & 7,883 & \\
\hline DUYGBAĞ6 & $0,638^{* *}$ & 0,139 & 7,979 & \\
\hline LIDERÜYE1 & $0,511 * *$ & - & - & \\
\hline LIDERÜYE2 & $0,519 * *$ & 0,158 & 6,717 & \\
\hline LIDERÜYE3 & $0,485^{* *}$ & 0,153 & 6,423 & \\
\hline LIDERÜYE4 & $0,508 * *$ & 0,156 & 6,618 & \\
\hline LIDERÜYE5 & $0,577 * *$ & 0,158 & 7,165 & \\
\hline LIDERÜYE6 & $0,635^{* *}$ & 0,160 & 7,547 & \\
\hline LIDERÜYE7 & $0,674 * *$ & 0,160 & 7,775 & \\
\hline
\end{tabular}

Faktör analizinin geçerli olabilmesi için tüm faktör yüklerinin 0,40 ' 1 n üzerinde ve anlamlı olması yeterli görülmektedir (Meyers vd., 2006, s. 508; Hair vd., 2014, s. 114-115; Brown, 2015, s. 27). Gerçekleştirilen doğrulayıcı faktör analizi sonucunda iş tatmini ölçeği için faktör yüklerinin 0,496 ile 0,713 arasında, duygusal bağlılık ölçeği için faktör yüklerinin 0,417 ile 0,638 arasında ve lider-üye etkileşimi ölçeği için faktör yüklerinin 0,485 ile 0,674 arasında olduğu tespit edilmiştir. Ayrıca en düşük t değeri 5,909 olarak hesaplamıştır ve tüm faktör yükleri 0,01 önemlilik seviyesinde anlamlıdır. Uyum iyiliği kriterleri incelendiğinde ise tüm değerlerin 140abul edilebilir sinırlar içerisinde olduğu görülmektedir $(\chi 2 / \mathrm{sd}=1,655, \mathrm{GFI}=0,912$, TLI $=$ 
$0,920$, CFI $=0,931$, RMSEA $=0,045)$. Dolayısıyla iş tatmini, duygusal bağlılık ve lider-üye etkileşimi ölçekleri için tek faktörlük yapı doğrulanmıştır.

\section{Güvenilirlik Analizi}

Ölçeklere ilişkin yapı geçerliliğinin sağlanmasının ardından güvenilirliklerinin belirlenebilmesi için Cronbach alfa ve birleşik güvenilirlik değerleri hesaplanmıştır. Ölçekler için hesaplanan güvenilirlik değerleri Tablo 5'de gösterilmektedir.

Tablo 5. Cronbach Alfa ve Birleşik Güvenilirlik Değerleri

\begin{tabular}{|l|c|c|c|}
\hline Ölçek & $\begin{array}{c}\text { Ifade } \\
\text { Sayısı }\end{array}$ & $\begin{array}{c}\text { Cronbach } \\
\text { Alfa ( } \boldsymbol{\alpha})\end{array}$ & $\begin{array}{c}\text { Birleşik } \\
\text { Güvenilirlik } \\
\text { (CR) }\end{array}$ \\
\hline Olumlu Mizah & 4 & 0,735 & 0,742 \\
\hline Olumsuz Mizah & 2 & 0,721 & 0,731 \\
\hline iş Tatmini & 5 & 0,739 & 0,742 \\
\hline $\begin{array}{l}\text { Duygusal } \\
\text { Bağlılık }\end{array}$ & 6 & 0,726 & 0,732 \\
\hline $\begin{array}{l}\text { Lider-Üye } \\
\text { Etkileşimi }\end{array}$ & 7 & 0,762 & 0,761 \\
\hline
\end{tabular}

Güvenilirliğin sağlanabilmesi için Cronbach alfa ve/veya birleşik güvenilirlik değeri için genel olarak 14labul edilen alt sınır 0,70'dir (Nunnally ve Bernstein, 1994, s. 265; Morgan vd., 2011, s. 135; Hair vd., 2014, s. 123; Kline, 2016, s. 92; Sekaran ve Bougie, 2016, s. 290). Ancak baz1 araştırmacılar güvenilirlik değerinin 0,60 üzerinde olmasının da 141abul edilebilir olduğunu belirtmektedir (Hair vd., 2014, s. 123; Sekaran ve Bougie, 2016, s. 290). Tablo 5 incelendiğinde, analiz sonucunda tüm ölçekler için hem Cronbach alfa hem de birleşik güvenilirlik değerlerinin 0,70’in üzerinde olduğu görülmektedir. Bu çerçevede, araştırma kapsamında kullanılan tüm değişkenlerin güvenilirlik şartını sağladığı belirlenmiştir.

\section{Tanımlayıcı İstatistikler}

Hipotez testleri öncesinde araştırmada kullanılan değişkenlere ilişkin tanımlayıcı istatistikler incelenmiştir. Bu kapsamda araştırmada kullanılan değişkenlerin ortalama ve standart sapma değerleri ile tüm değişkenler arasındaki ilişkilerin araştırıldığı korelasyon analizi Tablo 6'da gösterilmektedir. 
Tablo 6. Ortalama, Standart Sapma ve Korelasyon Değerleri

\begin{tabular}{|l|c|c|c|c|c|c|c|}
\hline \multicolumn{1}{|c|}{ Değişkenler } & Ort. & S.S. & $\mathbf{1}$ & $\mathbf{2}$ & $\mathbf{3}$ & $\mathbf{4}$ & $\mathbf{5}$ \\
\hline 1. Olumlu Mizah & 3,126 & 0,859 & 1 & & & \\
\hline 2. Olumsuz Mizah & 2,615 & 1,096 & $-0,615^{* *}$ & 1 & & \\
\hline 3. İş Tatmini & 3,165 & 0,731 & $0,499^{* *}$ & $-0,464^{* *}$ & 1 & 1 \\
\hline 4. Duygusal Bağlıık & 3,124 & 0,754 & $0,400^{* *}$ & $-0,448^{* *}$ & $0,332^{* *}$ & 1 \\
\hline 5. Lider-Üye Etk. & 3,136 & 0,774 & $0,442^{* *}$ & $-0,504^{* *}$ & $0,434^{* *}$ & $0,442^{* *}$ & 1 \\
\hline
\end{tabular}

Not: ${ }^{*} p<0,05 ;{ }^{* *} p<0,01 ; N=325$

Tablo 6'da yer alan korelasyon değerleri incelendiğinde, araştırmada kullanılan değişkenler arasında beklenen yönde ve anlamlı ilişkiler bulunduğu görülmektedir. Bununla birlikte, değişkenler arasındaki ilişki katsayılarının 0,90’ın altında olduğu görülmektedir. Dolayısıyla araştırmada kullanılan değişkenler arasında çoklu doğrusal bağlantı olmadığı söylenebilmektedir (Kline, 2016, s. 71).

\section{Hipotez Testleri}

Araştırmada yöneticilerin olumlu ve olumsuz mizah kullanımının çalışan tutumları üzerindeki etkisi hiyerarşik regresyon analizi ile test edilmiştir. Analizlerde bağımsız değişkenler olarak olumlu mizah ve olumsuz mizah, bağımlı değişkenler olarak ise iş tatmini, duygusal bağlılık ve lider-üye etkileşimi değişkenleri kullanılmıştır. Analizlere demografik değişkenler kontrol değişkenleri olarak eklenmiştir. Gerçekleştirilen hiyerarşik regresyon analizine ilişkin bulgular Tablo 7'de gösterilmektedir.

Tablo 7. Hiyerarşik Regresyon Analizi Bulguları

\begin{tabular}{|c|c|c|c|c|c|c|}
\hline & \multicolumn{2}{|c|}{ İş Tatmini } & \multicolumn{2}{|c|}{ Duygusal Bağlılık } & \multicolumn{2}{|c|}{ Lider-Üye Etkileşimi } \\
\hline & 1. Așama & 2. Aşama & 1. Aşama & 2. Aşama & 1. Aşama & 2. Aşama \\
\hline \multicolumn{7}{|c|}{ Kontrol Değişkenleri } \\
\hline Cinsiyet & $-0,143^{*}$ & $-0,060$ & $-0,152 *$ & $-0,090$ & $-0,199 * *$ & $-0,121^{*}$ \\
\hline Medeni Durum & $-0,273 * *$ & $-0,139 *$ & $-0,112 *$ & $-0,081$ & $-0,254 * *$ & $-0,134 *$ \\
\hline Yaş & $0,148^{*}$ & 0,072 & 0,088 & 0,015 & $0,229 * *$ & $0,150^{*}$ \\
\hline Çalışma Süresi & 0,005 & 0,003 & 0,028 & 0,034 & $-0,031$ & $-0,024$ \\
\hline Çalışılan Sektör & 0,049 & $-0,019$ & 0,096 & 0,036 & 0,035 & $-0,030$ \\
\hline \multicolumn{7}{|c|}{ Bağımsız Değ işkenler } \\
\hline Olumlu Mizah & & $0,298^{* *}$ & & $0,152 *$ & & $0,156^{*}$ \\
\hline Olumsuz Mizah & & $-0,205 * *$ & & $-0,272 * *$ & & $-0,306 * *$ \\
\hline F Değeri & $12.157 * *$ & $21410 * *$ & $11489 * *$ & $16.632 * *$ & $16396 * *$ & $23617 * *$ \\
\hline $\mathrm{R}^{2}$ & 0,160 & 0,321 & 0,153 & 0,269 & 0,204 & 0,343 \\
\hline Düzeltilmiş $\mathrm{R}^{2}$ & 0,147 & 0,306 & 0,139 & 0,252 & 0,192 & 0,328 \\
\hline$\Delta \mathrm{R}^{2}$ & & $0,161^{* *}$ & & $0,116^{* *}$ & & 0,139 ** \\
\hline
\end{tabular}

Not: ${ }^{*} p<0,05 ;{ }^{* *} p<0,01 ; N=325$

Araştırmanın ilk hipotezi, yöneticilerin olumlu ve olumsuz mizah kullanımı ile iş tatmini arasındaki ilişkiye odaklanmaktadır. Analiz sonucunda olumlu mizah kullanımındaki artışın iş tatmininde artışa neden olduğu (H1a: $\beta=0,298, p<0,01)$, olumsuz mizah kullanımındaki artışın 
ise iş tatmininde azalışa neden olduğu belirlenmiştir $(H 1 b: \beta=-0,205, p<0,01)$. Dolayısıyla H1a ve H1b hipotezleri kabul edilmiştir.

İkinci hipotezde, yöneticilerin olumlu ve olumsuz mizah kullanımı ile duygusal bağlılık arasındaki ilişkiyi araştırılmaktadır. Bulgulara göre, hem olumlu hem de olumsuz mizahın duygusal bağlılık üzerinde etkisi vardır. Yöneticilerin daha fazla olumlu mizah kullanımı, duygusal bağlılıkta artış (H2a: $\beta=0,152, \mathrm{p}<0,05)$, olumsuz mizah kullanımı ise azalış meydana getirmektedir ( $\mathrm{H} 2 \mathrm{~b}: \beta=-0,272, \mathrm{p}<0,01)$. Bu bulgu $\mathrm{H} 2 \mathrm{a}$ ve $\mathrm{H} 2 \mathrm{~b}$ hipotezlerin kabul edildiğ anlamina gelmektedir.

Üçüncü hipotez ile yöneticilerin olumlu ve olumsuz mizah kullanımıyla lider-üye etkileşimi arasındaki ilişki test edilmektedir. Analiz sonucunda olumlu mizah kullanımındaki artışın lider-üye etkileşimi algısında artışa neden olduğu (H3a: $\beta=0,156, p<0,05)$, olumsuz mizah kullanımındaki artışın ise lider-üye etkileşimi algısında azalışa neden olduğu belirlenmiştir (H3b: $\beta=-0,306, p<0,01)$.

\section{Tartışma ve Sonuç}

$\mathrm{Bu}$ araştırma ile yöneticinin mizah kullanım tarzının çalışan tutumlarını nasıl etkilediği incelenmektedir. Araştırmanın amacı, yöneticinin olumlu ve olumsuz mizah kullanımı ile iş tatmini, duygusal bağlılık ve lider-üye etkileşimi arasındaki ilişkiyi ortaya koymaktır. Bu amaçla farklı kurumlarda çalışan 325 kişiden anket yoluyla veriler toplanmıştır.

Araştırmada yöneticilerin daha fazla olumlu mizah kullanmasının iş tatmininde, duygusal bağlılıkta ve lider-üye etkileşimi algısında artışa neden olduğu belirlenmiştir. Diğer bir ifadeyle, yöneticiler iyi niyeti arttırma ve sıcak, sosyal ilişkiler geliştirme amacıyla çalışanlarına esprili yaklaştı̆̆ında çalışanlar bu durumdan memnun olmaktadır. Yöneticisinin fikralar anlatarak ve komik şakalar yaparak kendisiyle ilişkisini geliştirdiğine inanan çalışan hem işine hem örgütüne hem de yöneticisine daha fazla bağlanmaktadır. Analizler kapsamında ortaya konulan bu bulgunun, daha önce benzer ilişkileri inceleyen diğer çalışmalarla tutarlı olduğu görülmektedir (Recepoğlu, 2008; Romero ve Arendt, 2011; Mesmer-Magnus vd., 2012; Adıgüzel vd., 2014; Batool vd., 2014; Pundt ve Herrmann, 2015; Robert vd., 2016).

Genel olarak araştırmalarda, yöneticilerin olumlu mizah kullanımının her ne kadar hedeflerle doğrudan ilişkisi bulunmasa da, pek çok örgütsel sonucunun olduğu düşünülmektedir. Araştırmalar, mizahın diğer insanları eğlendirmek, ilişkileri iyileştirmek ve ortamı keyifli hale getirmek için kullanılmasının örgütsel problemlerin çözümü için kullanılabilecek önemli bir araç olduğunu belirtmektedir (Ford vd., 2003; Romero ve Cruthirds, 2006; Mesmer-Magnus vd., 2012). Bu çerçevede, gerçekleştirilen araştırmanın bulguları, daha önceki araştırmaların bulgularını destekler niteliktedir.

Araştırmanın diğer bir bulgusu da, yöneticilerin daha fazla olumsuz mizah kullanmasının iş tatmininde, duygusal bağlılıkta ve lider-üye etkileşimi algısında azalışa neden olduğudur. Bunun anlamı, yöneticilerin çalışanlarıyla ilişkilerinde mizahı iğnelemek, alay etmek, takılmak, 
dalga geçmek, aşağılamak veya küçük düşürmek amacıyla kullanması çalışan tutumlarında olumsuzluklar meydana getirmektedir. Diğer bir ifadeyle, yöneticilerin, çalışanlarını incitecek veya uzaklaştırabilecek mizahi ifadeleri sıklıkla kullanması sonucunda, çalışanların işinden duyduğu memnuniyet, kendisini örgütüyle bütünleştirmesi ve yönetici ile arasındaki profesyonel ilişkinin kalitesi olumsuz şekilde etkilenmektedir. Her ne kadar olumsuz mizahın örgütlerde etkileri üzerine çok sayıda çalışma bulunmasa da, elde edilen bu bulgunun benzer ilişkiyi araştıran bazı çalışmalarla tutarlı olduğu söylenebilir (Romero ve Arendt, 2011; Wisse ve Rietzschel, 2014; Sobral ve Islam, 2015; Robert vd., 2016). Fakat benzer ilişkiyi araştıran bazı çalışmalarda ise olumsuz mizahın örgütsel faktörler üzerinde bir etkisi belirlenememiştir (Cann vd. 2014).

Olumsuz mizah kullanımı ile çalışan tutumları arasındaki ilişkiyi inceleyen araştırmalarda, olumsuz mizah kullanımının yönetici ve çalışan arasındaki ilişkiye zarar verdiği ve bu tür mizah kullanan yöneticilerin, mizahın çalışanlar üzerindeki yaralayıcı etkilerini dikkate almadığı belirtilmektedir. Olumsuz mizah kullanmayı tercih eden yöneticiler, insanlarla alay etmek ve dalga geçmek, hataları için insanları eleştirmek ve kızdırmak ve en genel şekilde insanları bastırmak istemektedir. Dolayısıyla yöneticilerin mizah kullanımında olumsuz bir tarz benimsemesi, çalışanların yönetici ile olumlu ilişkiler kurmasını zorlaştırmaktadır (Pundt ve Herrmann, 2015).

Ayrıca analizler sonucunda, yöneticinin olumsuz mizah kullanımının çalı̧an tutumları üzerinde, olumlu mizah kullanımına nazaran daha güçlü bir etkiye sahip olduğu saptamıştır. Benzer bulgu Sobral ve Islam (2015) tarafından gerçekleştirilen çalışmada da bulunmaktadır. Dolayısıyla, yöneticinin çalı̧̧anlarıyla ilişkilerinde olumlu mizah kullanması her ne kadar önemli bir faktörse de, olumsuz mizahı kesinlikle tercih etmemesi örgütsel çıktılar açısından çok daha önemlidir.

Gerçekleştirilen araştırma hem mizah teorisine hem de örgüt yöneticilerine ve çalışanlarına çeşitli katkılar sağlamaktadır. Araştırma, özellikle çalışan tutumları üzerinde yönetici mizahının rolüne işaret etmektedir. Diğer çalışmaların da gösterdiği şekilde yöneticinin mizah kullanımı çeşitli örgütsel çıtıtları etkilemektedir (Romero ve Arendt, 2011; Mesmer-Magnus vd., 2012; Pundt ve Herrmann, 2015). Gerçekleştirilen araştırma bulguları daha önceki araştırma bulgularını destekler niteliktedir. Önceki araştırmaların, sosyal ilişkileri başlatmak ve sürdürmek için mizahın genel rolünün altını çizdiği görülmektedir. Bu araştırma ise, yönetici mizahının, hiyerarşik olarak farklı statüdeki insanlar arasındaki olumlu ilişkileri başlatmak ve sürdürmek veya olumsuz ilişkiler ortaya çıkarmak için bir rol oynadığına dair kanıtlar sunmaktadır. Ayrıca, örgütlerde mizah ve yöneticilerin mizah kullanımı üzerine yapılan araştırmaların çoğunlukla olumlu mizah üzerine yoğunlaştığı görülmektedir. Bu araştırma mizahın örgütsel sonuçlarını araştıırken hem olumlu hem de olumsuz mizah kullanımına odaklanmakta, bu yönüyle mizah teorisine önemli katkı sağlamaktadır.

Bununla birlikte araştırmanın bazı kısıtları da bulunmaktadır. İlk olarak, araştırmanın analiz sürecinde kesitsel veri kullanılmıştır. Kesitsel veri, değişkenler arasındaki nedensel ilişkiler 
hakkındaki kesin sonuçları sınırlandırmaktadır. Gelecekteki araştırmalar, boylamsal veriler veya deneysel tasarım yoluyla nedensellik hakkında daha ikna edici kanıtlar sağlayabilir. İkinci olarak, verilerin toplandığı örneklem farklı örgütlerdeki ve farklı kademelerdeki çalışanlardan oluşmaktadır. Dolayısıyla, elde edilen bulgular, belirli bir sektörden veya belirli bir örgütten toplanan veriler kapsamında farklılaşabilmektedir. Üçüncü olarak ise, araştırma kapsamında yöneticilerin olumlu ve olumsuz mizah kullanımının yalnızca belirli çalışan tutumları üzerindeki etkisi araştırılmıştır. Daha sonraki çalışmalar kapsamında mizah kullanımının tutumlarla birlikte çalışan davranışlarına odaklanması, elde edilen bulguların geliştirilmesi açısından faydalı olacaktır.

$\mathrm{Bu}$ araştırma ile son yıllarda daha fazla ilgi gösterilen fakat henüz net bulgulara ulaşılmamış bir alana katk1 sağlandığı düşünülmektedir. Araştırma sonucunda elde edilen bulgular, yöneticilerin olumlu ve olumsuz mizah kullanımının iş tatmini, duygusal bağlllık ve lider-üye etkileşimi ile ilişkili olduğuna dair kanıtlar sunmaktadır. Bu bulgular, örgüt ile çalışan arasındaki ilişkilerin geliştirilmesinde yöneticinin mizah kullanımının rolüne işaret etmektedir. Ayrıca, yöneticinin olumlu ve olumsuz mizah kullanımı arasında ayrım yapılması örgütsel çıktılar açısından yararlı görünmektedir. Fakat, her ne kadar bu çalışma mizahın örgütler için değerli olabileceği fikrini desteklese de, daha fazla araştırmanın yapılması gerekmektedir. Bu kapsamda, farklı mizah tarzlarının çeşitli bireysel sonuçları, farklı kişilik özelliklerine sahip yöneticilerin mizah kullanımı ve takım üyeleri tarafından paylaşılan kolektif mizah tarzları gibi alanlarda gerçekleştirilecek çalışmalar ile örgütsel davranış alanına daha fazla katkı sağlanabileceği söylenebilir.

\section{Kaynakça}

Adıgüzel, O., Erdoğan, A. \& Edinse, S. (2014). İş yerinde mizah ve örgütsel bağllık arasındaki ilişki. Research Journal of Business and Management, 1(4): 389-407.

Allen, N. J. \& Meyer, J. P. (1990). The measurement and antecedents of affective continuance and normative commitment to the organization. Journal of Occupational Psychology, 63(1): 1-18. doi: 10.1111/j.2044-8325.1990.tb00506.x.

Basım, H. N. \& Şeşen, H. (2009). Örgütsel Adalet Algısı-Örgütsel Vatandaşlık Davranışı İlişkisinde İş Tatmininin Aracılık Rolü. 17. Yönetim ve Organizasyon Kongresi Bildiriler Kitabı, 21-23 Mayıs, Eskişehir.

Batool, S. S., Zubair, S. Z. \& Batool, S. A. (2014). Does humor predict job satisfaction? A mediational role of self- efficacy. Pakistan Journal of Social and Clinical Psychology, 12(1): $12-16$.

Booth-Butterfield, S. \& Booth-Butterfield, M. (1991). Individual differences in the communication of humorous messages. Southern Communication Journal, 56(3): 205218. doi: $10.1080 / 10417949109372831$.

Brown, T. A. (2015). Confirmatory Factor Analysis for Applied Research. (2. Baskı). New York: The Guilford Press. 
Butler, N. (2016). Humour and Organization. Mir, R., Willmott, H. ve Greenwood, M. (Ed.), The Routledge Companion to Philosophy in Organization Studies içinde (s. 421-429). London: Routledge.

Byrne, B. M. (2016). Structural Equation Modeling with AMOS: Basic Concepts, Applications, and Programming. (3. Bask1). New York: Routledge.

Büyükyılmaz, O. (2018). İş Hayatında Mizah Kullanımı: Mizahın Çalışan Tutum ve Davranışları Üzerindeki Etkileri. Bursa: Ekin.

Cann, A., Watson, A. J. \& Bridgewater, E. A. (2014). Assessing humor at work: The humor climate questionnaire. Humor: International Journal of Humor Research, 27(2): 307-323. doi: 10.1515/humor-2014-0019.

Cooper, C. D. (2005). Just joking around? Employee humor expression as an ingratiatory behavior. Academy of Management Review, 30(4), 765-776. doi: 10.5465/AMR.2005.18378877.

Cooper, C. (2008). Elucidating the bonds of workplace humor: A relational process model. Human Relations, 61(8): 1087-1115. doi: 10.1177/0018726708094861.

Decker, W. H. \& Rotondo, D. M. (2001). Relationships among gender, type of humor, and perceived leader effectiveness. Journal of Managerial Issues, 13(4), 450-465.

Decker, W. H., Yao, H. ve Calo, T. J. (2011). Humor, gender, and perceived leader effectiveness in China. SAM Advanced Management Journal, 76(1): 43-53.

Dikkers, J., Doosje, S. \& de Lange, A. (2012). Humor as A Human Resource Tool in Organizations. Houdmont, J., Leka, S. \& Sinclair, R. R. (Ed.), Contemporary Occupational Health Psychology: Global Perspectives on Research and Practice, Volume: 2 içinde (s. 7491). Chichester: Wiley-Blackwell. doi: 10.1002/9781119942849.ch5.

Doosje, S., De Goede, M., Van Doornen, L. \& Goldstein, J. (2010). Measurement of occupational humorous coping. Humor: International Journal of Humor Research, 23(3), 275-305. doi: 10.1515/HUMR.2010.013

Duncan, W. J., Smeltzer, L. R. \& Leap, T. L. (1990). Humor and work: Applications of joking behavior to management. Journal of Management, 16(2),255-278. doi: $10.1177 / 014920639001600203$.

Durna, U. \& Eren, V. (2005). Üç bağll1lk unsuru ekseninde örgütsel bağlllık. Doğuş Üniversitesi Dergisi, 6(2), 210-219.

Ford, R., McLaughlin, F. \& Newstrom, J. W. (2003). Questions and answers about fun at work. human resource. Planning, 26(4), 18-33.

Galloway, G. \& Cropley, A. (1999). Benefits of humor for mental health: Empirical findings and directions for further research. Humor: International Journal of Humor Research, 12(3), 301-314. doi: 10.1515/humr.1999.12.3.301

Gervais, M. \& Wilson, D. S. (2005). The evolution and functions of laughter and humor: A synthetic approach. The Quarterly Review of Biology, 80(4), 395-430. doi: 10.1086/498281.

Gkorezis, P., Petridou, E. \& Xanthiakos, P. (2014). Leader positive humor and organizational cynicism: LMX as a mediator. Leadership \& Organization Development Journal, 35(4), 305-315. doi: 10.1108/LODJ-07-2012-0086. 
Graen, G. B. \& Scandura, T. A. (1987). Toward A Psychology of Dyadic Organizing. Staw, B. M. ve Cummings, L. L. (Ed.), Research in Organizational Behavior 9 içinde (s. 175-208), Greenwich, CT: JAI.

Graen, G. B. \& Uhl-Bien, M. (1995). Relationship-based approach to leadership: Development of Leader-Member Exchange (LMX) theory of leadership over 25 years: Applying a multilevel multi-domain perspective. Leadership Quarterly, 6(2), 219-247. doi: 10.1016/10489843(95)90036-5

Gürkan, G. Ç. (2006). Örgütsel Bağlllık: Örgütsel İklimin Örgütsel Bağlılık Üzerindeki Etkisi ve Trakya Üniversitesi'nde Örgüt İklimi ile Örgütsel Bağlllık Arasındaki İlişkinin Araştırılması. (Yayımlanmamış yüksek lisans tezi). Trakya Üniversitesi/Sosyal Bilimler Enstitüsü, Edirne.

Hackman, J. R. \& Oldham, G. R. (1975). Development of the job diagnostic survey. Journal of Applied Psychology, 60(2), 159-170. doi: 10.1037/h0076546.

Hair, J. F., Black, W. C., Babin, B. J. \& Anderson, R. E. (2014). Multivariate Data Analysis. (7th Edition), Harlow: Pearson New International Edition.

Hall, J. A. (2017). Humor in romantic relationships: A meta-analysis. Personal Relationships, 24(2), 306-322. doi: 10.1111/pere.12183.

Hampes, W. P. (2005). Correlations between humor styles and loneliness. Psychological Reports, 96(3), 747-750. doi: 10.2466/pr0.96.3.747-750.

Holmes, J. (2007). Making humour work: Creativity on the job. Applied Linguistics, 28(4), 518537. doi: 10.1093/applin/amm048.

Holmes, J. \& Marra, M. (2002). Over the edge? Subversive humor between colleagues and friends. Humor: International Journal of Humor Research, 15(1), 65-87. doi: 10.1515/humr.2002.006.

Hughes, L. W. \& Avey, J. B. (2009). Transforming with Levity: Humor, leadership, and follower attitudes. Leadership \& Organization Development Journal, 30(6), 540-562, doi: 10.1108/01437730910981926.

Hurren, B. L. (2006). The effects of principals' humor on teachers' job satisfaction. Educational Studies, 32(4), 373-385. doi: 10.1080/03055690600850321.

Janes, L. \& Olson, J. (2015). Humor as An Abrasive or A Lubricant in Social Situations: Martineau Revisited. Humor: International Journal of Humor Research, 28(2), 271-288. doi: 10.1515/humor-2015-0021.

Karcıoğlu, F. \& Kahya, C. (2011). Lider-üye etkileşimi ve çatışma yönetim stili ilişkisi. Atatürk Üniversitesi Sosyal Bilimler Enstitüsü Dergisi, 15(2): 337-352.

Kline, R. B. (2016). Principles and Practice of Structural Equation Modeling. (4. Bask1), New York: The Guilford Press.

Kuiper, N. A. \& Harris, A. L. (2009). Humor styles and negative affect as predictors of different components of physical health. Europe's Journal of Psychology, 5(1), 1-18. doi: 10.5964/ejop.v5i1.280.

Liden, R. C. \& Maslyn, J. M. (1998). Multidimensionality of leader-member exchange: an empirical assessment through scale development. Journal of Management, 24(1), 43-72. doi: 10.1016/S0149-2063(99)80053-1. 
Liu, Y. \& Wang L. (2016). A review of organization humor: Concept, measurement and empirical research. Psychology, 7(10), 1307-1314.

doi: 10.4236/psych.2016.710132.

Locke, E. A. (1976). The Nature and Causes of Job Satisfaction. Dunnelle, M. D. (Ed.), Handbook of Industrial and Organizational Psychology içinde (s. 1297-1343), Chicago: Rand McNally.

Long, D. L. \& Graesser, A. C. (1988). Wit and humor in discourse processing, Discourse Processes, 11(1), 35-60. doi: 10.1080/01638538809544690.

Luthans, F. (1995). Organizational Behavior. (7. Baskı), New York: McGraw-Hill.

Lyttle, J. (2007). The judicious use and management of humor in the workplace. Business Horizons, 50(3), 239-245. doi: 10.1016/j.bushor.2006.11.001.

Martin, R. A. (2001). Humor, laughter, and physical health: Methodological issues and research findings. Psychological Bulletin, 127(4), 504-519. doi: 10.1037//0033-2909.127.4.504.

Martin, R. A. (2007). The Psychology of Humor: An Integrative Approach. California, USA: Elsevier Academic.

Martin, R. A., Puhlik-Doris P., Larsen G., Gray, J. \& Weir, K. (2003). Individual differences in uses of humor and their relation to psychological well-being: Development of the humor styles questionnaire. Journal of Research in Personality, 37(1), 48-75. doi: 10.1016/S00926566(02)00534-2.

Martineau, W. H. (1972). A Model of The Social Functions of Humor. Goldstein, J. H. ve McGhee, P E. (Ed.), The Psychology of Humor: Theoretical Perspectives and Empirical Issues içinde (s. 101-125), New York: Academic. doi: 10.1016/B978-0-12-288950-9.500110 .

Mendiburo-Seguel, A., Páez, D. \& Martínez-Sánchez, F. (2015). Humor styles and personality: a meta-analysis of the relation between humor styles and the big five personality traits. Scandinavian Journal of Psychology, 56(3), 335-340. doi: 10.1111/sjop.12209.

Mesmer-Magnus, J., Glew, D. J. \& Viswesvaran, C. (2012). A meta-analysis of positive humor in the workplace. Journal of Managerial Psychology, 27(2), 155-190. doi: $10.1108 / 02683941211199554$.

Meydan, C. H. \& Şeşen, H. (2011). Yapısal Eşitlik Modellemesi: AMOS Uygulamaları, Ankara: Detay.

Meyer, J. C. (2015). Understanding Humor Through Communication. New York: Lexington Books.

Meyer, J. P. \& Allen, N. J. (1991). A three-component conceptualization of organizational commitment. Human Resource Management Review, 1(1), 61-89. doi: 10.1016/10534822(91)90011-Z.

Meyer, J. P., Allen, N. J. \& Smith, C. A. (1993). Commitment to organizations and occupations: extension and test of a three-component conceptualization. Journal of Applied Psychology, 78(4), 538-551. doi: 10.1037/0021-9010.78.4.538

Meyer, J. P., Stanley, D. J., Herscovitch, L. \& Topolnytsky, L. (2002). Affective, continuance, and normative commitment to the organization: A meta-analysis of antecedents, correlates, and consequences. Journal of Vocational Behavior, 61(1), 20-52. doi: 10.1006/jvbe.2001.1842. 
Meyers, L. S., Gamst, G. \& Guarino, A. J. (2006). Applied Multivariate Research: Design and Interpretation. Thousand Oaks: Sage.

Morgan, G. A., Leech, N. L., Gloeckner, G. W. \& Barrett, K. C. (2011). IBM SPSS for Introductory Statistics: Use and Interpretation. (4. Bask1), New York: Routledge.

Nunnally, J. C. \& Bernstein, I. H. (1994). Psychometric Theory. (3rd Edition), New York: McGraw-Hill Inc.

Özutku, H., Ağca, V. \& Cevrioğlu, E. (2008). Lider-Üye Etkileşim Teorisi Çerçevesinde, Yönetici-Ast Etkileşimi ile Örgütsel Bağlılık Boyutları ve İş Performansı Arasındaki İlişki: Ampirik Bir Inceleme. Atatürk Üniversitesi İktisadi ve İdari Bilimler Dergisi, 22(2), 193 210.

Plester, B. (2009). Crossing the line: Boundaries of workplace humour and fun. Employee Relations, 31(6), 584-599. doi: 10.1108/01425450910991749.

Pundt, A. \& Herrmann, F. (2015). Affiliative and aggressive humour in leadership and their relationship to leader-member exchange. Journal of Occupational and Organizational Psychology, 88(1), 108-125. doi: 10.1111/joop.12081.

Quinn, B. A. (2000). The paradox of complaining: Law, humor, and harassment in the everyday work world. Law \& Social Inquiry, 25(4), 1151-1185. doi: 10.1111/j.17474469.2000.tb00319.x.

Recepoğlu, E. (2008). Okul Müdürlerinin Mizah Yeteneğinin Öğretmenlerin İş Doyumlarına Etkisi. Eğitim ve Bilim, 33(150), 74-86.

Robert, C. \& Yan, W. (2007). The Case for Developing New Research on Humor and Culture in Organizations: Toward A Higher Grade of Manure. Martocchio, J. J. (Ed.), Research in Personnel and Human Resource Management, Vol. 26 içinde (s. 205-267), Emerald Group Publishing Limited. doi: 10.1016/S0742-7301(07)26005-0.

Robert, C. \& Veiga, S. P. da M. (2017). conversational humor and job satisfaction at work: exploring the role of humor production, appreciation, and positive affect. Humor: International Journal of Humor Research, 30(4), 417-438. doi: 10.1515/humor-2017-0034.

Robert, C. \& Wilbanks, J. E. (2012). The wheel model of humor: Humor events and affect in organizations. Human Relations, 65(9), 1071-1099. doi: 10.1177/0018726711433133.

Robert, C., Dunne, T. C. \& Iun, J. (2016). The impact of leader humor on subordinate job satisfaction: The crucial role of leader-subordinate relationship quality. Group \& Organization Management, 41(3), 375-406. doi: 10.1177/1059601115598719.

Romero, E. J. \& Arendt, L A. (2011). Variable effects of humor styles on organizational outcomes. Psychological Reports, 108(2), 649-659. doi: 10.2466/07.17.20.21.PR0.108.2.649-659.

Romero, E. J. \& Cruthirds, K. W. (2006). The use of humor in the workplace. The Academy of Management Perspectives, 20(2), 58-69. doi: 10.5465/AMP.2006.20591005.

Romero, E. ve Pescosolido, A. (2008). Humor and group effectiveness. Human Relations, 61(3), 395-418. doi: 10.1177/0018726708088999

Scandura, T. A. \& Graen, G. B. (1984). Moderating effects of initial leader-member exchange status on the effects of a leadership intervention. Journal of Applied Psychology, 69(3), 428436. doi: 10.1037/0021-9010.69.3.428. 
Scheel, T. \& Gockel, C. (2017). Humor at Work in Teams, Leadership, Negotiations, Learning and Health. Cham, Switzerland: Springer International Publishing.

Schumacker, R. E. \& Lomax, R. G. (2010). A Beginner's Guide to Structural Equation Modeling. (3rd Edition), New York: Routledge.

Sekaran, U. \& Bougie, R. (2016). Research Methods for Business: A Skill-Building Approach. (7. Bask1), Chichester: Wiley.

Sığrı, Ü. (2007). İş Görenlerin Örgütsel Bağlılıklarının Meyer ve Allen Tipolojisiyle Analizi: Kamu ve Özel Sektörde Karşılaştırmalı Bir Araştırma. Anadolu Üniversitesi Sosyal Bilimler Dergisi, 7(2), 261-278.

Sobral, F. \& Islam, G. (2015). He who laughs best, leaves last: The influence of humor on the attitudes and behavior of interns. Academy of Management Learning \& Education, 14(4), 500-518. doi: 10.5465/amle.2013.0368.

Şeşen, H. (2010). Öncülleri ve Sonuçları ile Örgüt İçi Girişimcilik: Türk Savunma Sanayinde Bir Araştırma. (Yayımlanmamış doktora tezi). Kara Harp Okulu Savunma Bilimleri Enstitüsü, Ankara.

Tabachnick, B. G. \& Fidell, L. S. (2013). Using Multivariate Statistics. (6. Bask1), Boston, Mass: Pearson International Edition.

Taşçı, D., Kırel, Ç., \& Kıyık Kıcır, G. (2016). Medya Endüstrisinde Kamu ve Özel Sektör Çalışanlarının, Örgütsel Bağlılık Konusu Bağlamında Karşılaştırmalı Analizi. Anadolu Üniversitesi Sosyal Bilimler Dergisi, 16(3), 129-152.

Wanzer, M., Booth-Butterfield, M. \& Booth-Butterfield, S. (2005). "If we didn't use humor, we'd cry": Humorous coping communication in health care settings. Journal of Health Communication, 10(2), 105-125. doi: 10.1080/10810730590915092.

Wilbur, C. J. \& Campbell, L. (2011). Humor in romantic contexts: Do men participate and women evaluate?. Personality and Social Psychology Bulletin, 37(7), 918-929. doi: $10.1177 / 0146167211405343$.

Wisse, B. \& Rietzschel, E. (2014). Humor in Leader-Follower Relationships: Humor Styles, Similarity and Relationship Quality. Humor: International Journal of Humor Research, 27(2), 249-269. doi: 10.1515/humor-2014-0017.

Wood, R. E., Beckmann, N. \& Rossiter, J. R. (2011). Management humor: Asset or liability? Organizational Psychology Review, 1(4), 316-338. doi: 10.1177/2041386611418393. 